\title{
Bifunctional chiral dehydroalanines for peptide coupling and stereoselective S-Michael addition
}

Gutiérrez-Jiménez, Marta I.; Aydillo, Carlos; Navo, Claudio D.; Avenoza, Alberto; Corzana,

Francisco; Jiménez-Osés, Gonzalo; Zurbano, María M.; Busto, Jesús H.; Peregrina, Jesús M.

\section{Published in:}

Organic Letters

DOI:

10.1021/acs.orglett.6b00840

Publication date:

2016

Document version

Publisher's PDF, also known as Version of record

Document license:

Other

Citation for published version (APA):

Gutiérrez-Jiménez, M. I., Aydillo, C., Navo, C. D., Avenoza, A., Corzana, F., Jiménez-Osés, G., Zurbano, M. M., Busto, J. H., \& Peregrina, J. M. (2016). Bifunctional chiral dehydroalanines for peptide coupling and stereoselective S-Michael addition. Organic Letters, 18(12), 2796-2799.

https://doi.org/10.1021/acs.orglett.6b00840 


\section{Bifunctional Chiral Dehydroalanines for Peptide Coupling and Stereoselective S-Michael Addition}

Marta I. Gutiérrez-Jiménez, ${ }^{\dagger, \|}$ Carlos Aydillo, ${ }^{\ddagger}, \|$ Claudio D. Navo, ${ }^{\dagger}$ Alberto Avenoza, ${ }^{\dagger}$ Francisco Corzana, ${ }^{\dagger}$ Gonzalo Jiménez-Osés, ${ }^{\dagger, \S}$ María M. Zurbano, ${ }^{\dagger}$ Jesús H. Busto, ${ }^{*}{ }^{\dagger}$ and Jesús M. Peregrina* ${ }^{*}{ }^{\dagger}$

${ }^{\dagger}$ Departamento de Química, Universidad de La Rioja, Centro de Investigación en Síntesis Química, E-26006 Logroño, Spain

${ }^{\ddagger}$ CECB, Department of Chemistry, University of Copenhagen, Universitetsparken 5, 2100 Copenhagen, Denmark

${ }^{\S}$ Institute of Biocomputation and Physics of Complex Systems (BIFI), University of Zaragoza, BIFI-IQFR (CSIC), 50018 Zaragoza, Spain

Supporting Information

ABSTRACT: A second generation of chiral bicyclic dehydroalanines easily accessible from serine has been developed. These scaffolds behaved as excellent $S$-Michael acceptors when tri- $O$-acetyl-2-acetamido-2-deoxy-1-thio- $\alpha$ D-galactopyranose (abbreviated as GalNAc- $\alpha$-SH) was used as a nucleophile. This addition proceeds with total chemo- and stereoselectivity, complete atom economy, quickly, and at room temperature, making it a true click reaction. The Michael adducts were easily transformed into $S$-(2-acetamido-2-deoxy- $\alpha$ D-galactopyranosyl)-L- and -D-cysteines, which can be regarded as mimics of the Tn antigen derived from L-Ser $(\alpha$-D-GalNAc-L-Ser) and D-Ser $(\alpha$-DGalNAc-D-Ser), respectively.

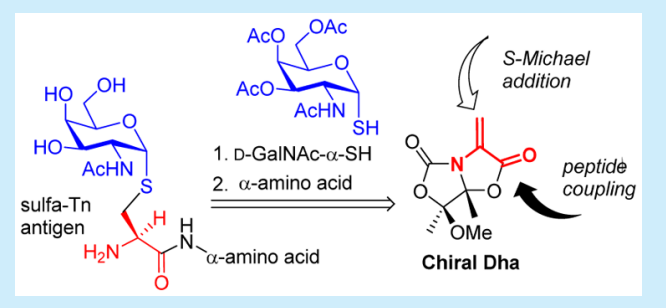

$\mathrm{T}$ he finding of the Tn antigen ( $\alpha$-D-GalNAc-L-Ser/Thr) and its unusual expression associated with tumor growth is considered an innovative point in the glycobiology field. ${ }^{1 \mathrm{a}}$ In the past decade, considerable efforts have been made toward the development of antitumor vaccines based on this simple structure. ${ }^{1}$ However, no cancer vaccines of this type have reached the clinic to date. ${ }^{2 a}$ This might be due to the sensitivity of these antigens to endogenous glycosidases, which decreases in vivo bioavailability. ${ }^{2 \mathrm{~b}, \mathrm{c}}$ Accordingly, several mimics of the $\mathrm{Tn}$ antigen based on diverse structural modifications have been proposed to improve immunogenicity of cancer vaccines. ${ }^{3}$ These approaches involved the preparation of modified mucin-like glycopeptides $^{4-7}$ or conformationally restricted Tn antigen mimics. ${ }^{8}$ Additionally, Tn antigen mimics based on cysteine $S$ glycosylation have been used. ${ }^{6 \mathrm{~b}, 9}$ Very recently, we have described that sulfa-Tn peptides are recognized by monoclonal anti-MUC1 antibodies. ${ }^{10}$ Since the discovery of cysteine $S$ glycosylation $^{11}$ as a new post-translational modification (PTM), ${ }^{12,13}$ several $S$-glycosylation methods have been developed. ${ }^{11,14}$ These methods use protected carbohydrates as electrophiles and Cys derivatives as nucleophiles and have been applied to the synthesis of $\beta$-S-glycosyl amino acids and $\beta$-Sglycopeptides. ${ }^{15,16}$ Conversely, the formation of the $\alpha$-Sglycosidic bond, ${ }^{15 c}$ especially involving the $\alpha$-S-GalNAc moiety present in the sulfa-Tn antigen $1,{ }^{16,17}$ has received less attention (Scheme 1). $\alpha$-Thio-linked glycosyl amino acids have been obtained by condensation of a $\beta$-bromoalanine derivative with the corresponding thiolate salt of the carbohydrate. ${ }^{17}$ On the other hand, dehydroalanine (Dha) ${ }^{18-20}$ is an unsaturated amino acid of both biological and synthetic interest ${ }^{18}$ used as chemical precursor to a range of site-selective PTM by the conjugate
Scheme 1. Retrosynthesis of Sulfa-Tn Antigen from Chiral Dha Derivatives

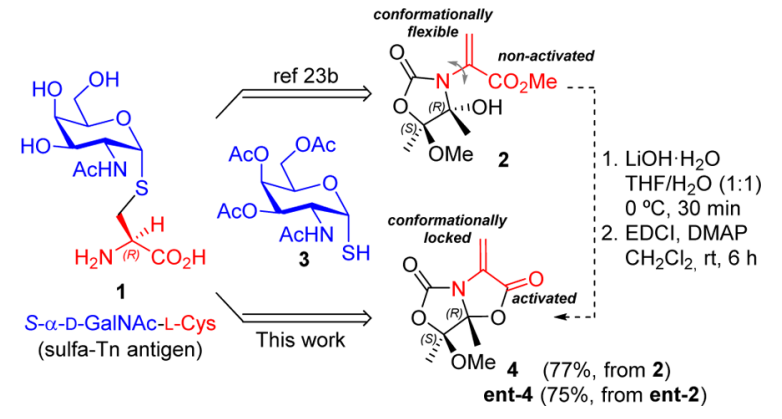

addition of thiols. ${ }^{20}$ For instance, thiols with large alkyl chains or fluorescent groups, cysteine derivatives, and thioacetate are examples of nucleophiles used to install PTM on peptides by this method. Moreover, Dha-containing peptides have been used as $S$-Michael acceptors for nucleophilic thiocarbohydrates, although with low diastereoselectivities. ${ }^{21,22}$ Motivated by the absence of highly stereocontrolled procedures for the selective formation of $\alpha$-S-glycosidic bonds from dehydroamino acids, we recently reported the inexpensive synthesis of a new chiral Dha derivative derived from serine (2) on a multigram scale. ${ }^{23 a}$ This substrate was used in stereoselective $S$-Michael additions of appropriately protected thiocarbohydrates such as tri-O-acetyl-2acetamido-2-deoxy-1-thio- $\alpha$-D-galactopyranose (3, abbreviated

Received: March 22, 2016

Published: June 1, 2016 
as GalNAc- $\alpha$-SH), with generally high yields and diastereoselectivities (Scheme 1). ${ }^{23 \mathrm{~b}}$ This procedure has been applied to the synthesis of $S$-(2-acetamido-2-deoxy- $\alpha$-D-galactopyranosyl)-Lcysteine 1 , which is regarded as a mimic of Tn antigen named sulfa-Tn antigen.

The key $S$-Michael addition step from Dha 2 and GalNAc- $\alpha$ SH 3 proceeded with a moderate yield $(67 \%) .{ }^{24}$ Moreover, in order to obtain a high diastereoselectivity, an organic base $(1,8$ diazabicycloundec-7-ene, DBU) and cryogenic temperatures ( $\mathrm{dr}$ $>95: 5$ at $-78{ }^{\circ} \mathrm{C}, \mathrm{dr}=41: 59$ at $25{ }^{\circ} \mathrm{C}$ ) were required, which might limit the scope of this transformation under milder and/or biocompatible conditions.

Once the role of the tertiary alcohol at the oxazolidin-2-one ring as a stereodirecting group in the S-Michael addition was discarded (Supporting Information), we envisioned that intramolecular lactonization of this alcohol with the methyl acrylate group would significantly reduce the conformational flexibility of 2 , potentially conferring more robust diastereoinducing properties to our chiral scaffold. Simultaneously, the formation of a fused oxazolidin-5-one ring could facilitate the final deprotection and/or activate the C-terminus of the resulting bicyclic dehydroamino acid (4), enabling facile peptide coupling reactions at this position (Scheme 1).

Thus, the new bicyclic Dha scaffold 4 was readily synthesized, on a gram scale, in two steps by basic hydrolysis of the methyl ester group of 2 followed by lactonization using 1-ethyl-3-(3(dimethylamino)propyl)carbodiimide (EDCI) as a coupling reagent in the presence of 4-(dimethylamino)pyridine (DMAP) as a base. The same procedure was applied to the corresponding enantiomer ent-4 starting from D-Ser (Scheme 1). The diastereomeric purity and stereochemistry of both substrates was maintained upon lactonization, as verified crystallographically (Supporting Information).

Both chiral Dha derivatives 4 and ent- 4 showed excellent Michael acceptor properties, cleanly reacting with GalNAc- $\alpha$-SH 3 with DBU as a base, under the same conditions reported ${ }^{23 b}$ for Dha derivative 2 . After $3 \mathrm{~h}$ of reaction in $\mathrm{THF}$ at $-78^{\circ} \mathrm{C}$, adduct $\mathbf{5}$ or $\mathbf{5}^{\prime}$ was obtained as a single diastereomer $(\mathrm{dr}>95: 5)$ in high yields (86-98\%, Supporting Information). The absolute configuration of the new stereocenter of compounds $\mathbf{5}$ and $\mathbf{5}^{\prime}$ created in the 1,4-conjugate addition was determined by NOESY-NMR experiments. In both cases, the observation of a medium-size NOE cross-peak between the hydrogens of the $-\mathrm{CH}_{2} \mathrm{~S}-$ substituent at the $\mathrm{C} 3$ and the $\mathrm{CH}_{3}$ group at $\mathrm{C} 7 \mathrm{a}$ of the 2,5-dioxotetrahydro-5H-oxazolo[4,3- $b$ ] oxazole rigid bicyclic system confirmed that $\mathrm{C} 3$ displays an $R$-configuration in compound $\mathbf{5}$ and an S-configuration in adduct $\mathbf{5}^{\prime}$ (Supporting Information). These structural features were confirmed by X-ray analysis of compound 5 (Supporting Information). This very same stereochemical outcome of the S-Michael addition was observed for the first-generation chiral Dhas 2 and ent-2, suggesting similar stereoselection pathways for both scaffolds. However, a significant difference was observed with respect to our firstgeneration chiral acrylates ( 2 and ent- 2 ), that is, the complete diastereoselectivity for the $S$-Michael addition observed at -78 ${ }^{\circ} \mathrm{C}$ with 4 is maintained at $25{ }^{\circ} \mathrm{C}$. After different concentrations and bases were explored (Supporting Information), the best conditions involved dropwise addition of equimolecular amounts of thiocarbohydrate and the use of THF as a solvent and triethylamine (TEA) as a base at $25{ }^{\circ} \mathrm{C}$, affording a $99 \%$ yield of adduct 5 with a diastereoselectivity $>95: 5$, on a gram scale (Scheme 2). The optimal reaction time $(5 \mathrm{~min})$ is the time necessary to slowly add the thiocarbohydrate; therefore, this $S$ -
Scheme 2. Diastereoselective $S$-Michael Addition of GalNAc$\alpha$-SH to Bicyclic Chiral Dha 4 and ent- 4 and Hydrolysis

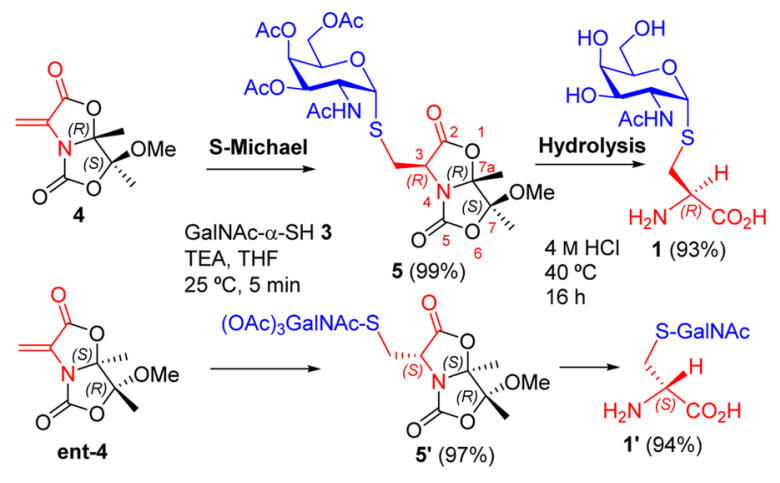

Michael addition can be regarded as a true click reaction. These conditions were also tested with Dha 2, affording a poor diastereoselectivity (Supporting Information).

In order to test the scope of the reaction, chiral Dha 4 was treated with several thiols $(\mathbf{a}-\mathbf{h})$ under similar conditions, the corresponding conjugate additions providing a wide panel of post-translational modifications that are commonly found on peptides and proteins. In all cases, each of the 1,4-conjugate adducts $(\mathbf{5 a}-\mathbf{h})$ was obtained as a unique stereoisomer with high yield and diastereoselectivity (Scheme 3 ). The absolute

Scheme 3. S-Michael Addition of Thiols a-g to Dha 4
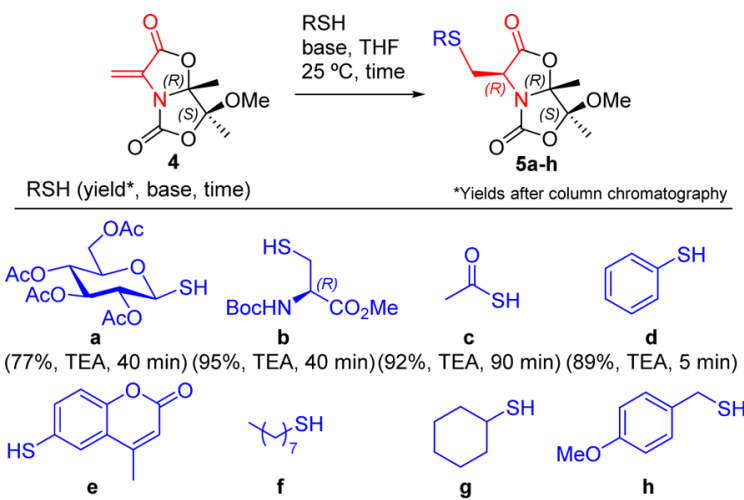

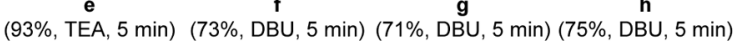

configuration of the new generated stereocenter was also determined by NOESY-NMR experiments (Supporting Information). We were delighted to observe that the same stereochemical outcome was maintained for all $S$-nucleophiles with Dha 4, unlike with Dha 2 . $^{23 a}$

These results indicate a robust stereoinduction mechanism for the protonation of the enolate adduct upon conjugate addition in Dha 4. The calculated structure of a model enolate using $\mathrm{MeS}^{-}$as a nucleophile revealed a slight pyramidalization of the enolic carbon $\left(\theta=8^{\circ}\right)$, suggesting a more favorable protonation by the concave $(\mathrm{Si})$ face (Figure 1$)$. The steric hindrance exerted by the bridgehead methyl group at position $7 \mathrm{a}$ and the appearance of torsional strain in the five-membered oxazolidin-5-one upon protonation of the enolate by the convex $(R e)$ face $^{25}$ also favor protonation by the, in principle, less accessible concave face, as demonstrated by transition-state (TS) calculations (Supporting Information).

Complete hydrolysis of $\mathbf{5}$ and $\mathbf{5}^{\prime}$ with aqueous $4 \mathrm{M} \mathrm{HCl}$ at 40 ${ }^{\circ} \mathrm{C}$ for $16 \mathrm{~h}$ yielded the corresponding S-GalNAc-L- and Dcysteine hydrochlorides $\mathbf{1}$ and $\mathbf{1}^{\prime}$ in good yields (93-94\%, 


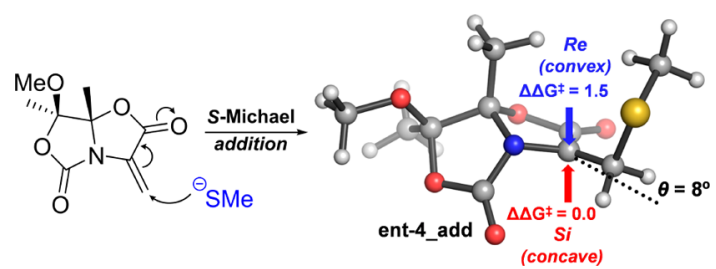

Figure 1. Mechanism of the S-Michael addition of methanethiol to ent-4 in the presence of an abbreviated DBU model as a base, calculated with $\mathrm{PCM}_{\mathrm{THF}} / \mathrm{M} 06-2 \mathrm{X} / 6-31+\mathrm{G}(\mathrm{d}, \mathrm{p})$. Relative activation barriers $\left(\Delta \Delta G^{\ddagger}\right)$ are given in $\mathrm{kcal} \mathrm{mol}^{-1}$. Only lowest energy structures are shown (other conformations are available in the Supporting Information).

Scheme 2). The stereochemical integrity of both the $\alpha$-carbon and the $\alpha$-S-glycosidic bond of these sulfa-Tn antigen derivatives was maintained upon deprotection, as verified by their optical and NMR properties (Supporting Information). Orthogonally protected versions of these $S$-glycosylated amino acids are readily accessible through our previous protocol. ${ }^{23 b}$

Apart from the synthetic advantages of these new bicyclic Michael acceptors $\mathbf{4}$ and ent-4 over $\mathbf{2}$ and ent-2 (highly stereoselective at noncryogenic temperatures, more reactive toward both $S$-Michael addition and subsequent deprotection, providing cleaner reactions and higher yields), they offer the attractive feature of their carboxylic acid group being effectively protected and activated for peptide coupling as an oxazolidin-5one. As a proof of concept, we coupled $\mathbf{5}$ and $\mathbf{5}^{\prime}$ with different $\alpha$ and $\beta$-amino ester hydrochlorides (Gly, Ala, Phe, unprotected Ser and $\beta$-Ala) in the presence of sodium 2 -ethylhexanoate as a base in moderate to good yields and without epimerization of the cysteine $\alpha$-carbon (Table 1 ). The acidic hydrolysis of selected adducts $7 \mathbf{b}, \mathbf{c}$ and $7 \mathbf{b}^{\prime}$ with $4 \mathrm{M} \mathrm{HCl}$ at $40{ }^{\circ} \mathrm{C}$ and subsequent purification by preparative HPLC gave enantiopure $S$ glycodipeptides L-Cys $(\alpha$-D-GalNAc)- $\beta$-Ala (8b) L-Cys $(\alpha$-DGalNAc)-L-Phe (8c), and D-Cys $\left(\alpha\right.$-D-GalNAc)- $\beta$-Ala $\left(\mathbf{8 b}^{\prime}\right)$ in good yields (Table 1 and Supporting Information).

In addition, the synthetic versatility of bicycles $\mathbf{4}$ and ent- $\mathbf{4}$ was further expanded by performing the peptide coupling reactions before the $S$-Michael addition step. Thus, bicycles $\mathbf{4}$ and ent-4 were directly coupled to several $\alpha$ - and $\beta$-amino ester hydrochlorides to provide dehydropeptides $9 c$ and $9 a^{\prime}-d^{\prime}$, respectively, in moderate yields under the aforementioned aminolysis conditions (Table 1). Of note, the addition of GalNAc- $\alpha$-SH to dehydrodipeptide $9 \mathrm{c}$ with TEA as a base at 25 ${ }^{\circ} \mathrm{C}$ yielded protected $S$-glycodipeptide $7 \mathrm{c}$ with identical complete diastereoselectivity than described above using the S-Michael/ aminolysis reactions sequence, with a good yield (97\%, Scheme 4). To discard the role of the configuration of L-Phe as a stereodirecting factor in the $S$-Michael addition of dehydropeptide 9c with GalNAc- $\alpha$-SH 3, we synthesized the dehydropeptide 9c-D-Phe and carried out the S-Michael addition under the same conditions obtaining high yield and diastereoselectivity with the same stereochemical outcome $(R)$ at the cysteine $\alpha$-carbon (Supporting Information). Although still under development, this strategy provides an effective entry to the programmable siteselective modification of dehydropeptides with high diastereoselectivity, a challenge that cannot be accomplished with classic Dha derivatives. $^{26}$

In summary, we have developed a new bicyclic chiral dehydroalanine that behaves as an excellent Michael acceptor in the stereoselective 1,4-conjugate addition of tri-O-acetyl-2acetamido-2-deoxy-1-thio- $\alpha$-D-galactopyranose in the presence of DBU or TEA as bases. This type of S-Michael addition
Table 1. Peptide Coupling through Ring-Opening Aminolysis of the Oxazolidin-5-one Followed by Hydrolysis

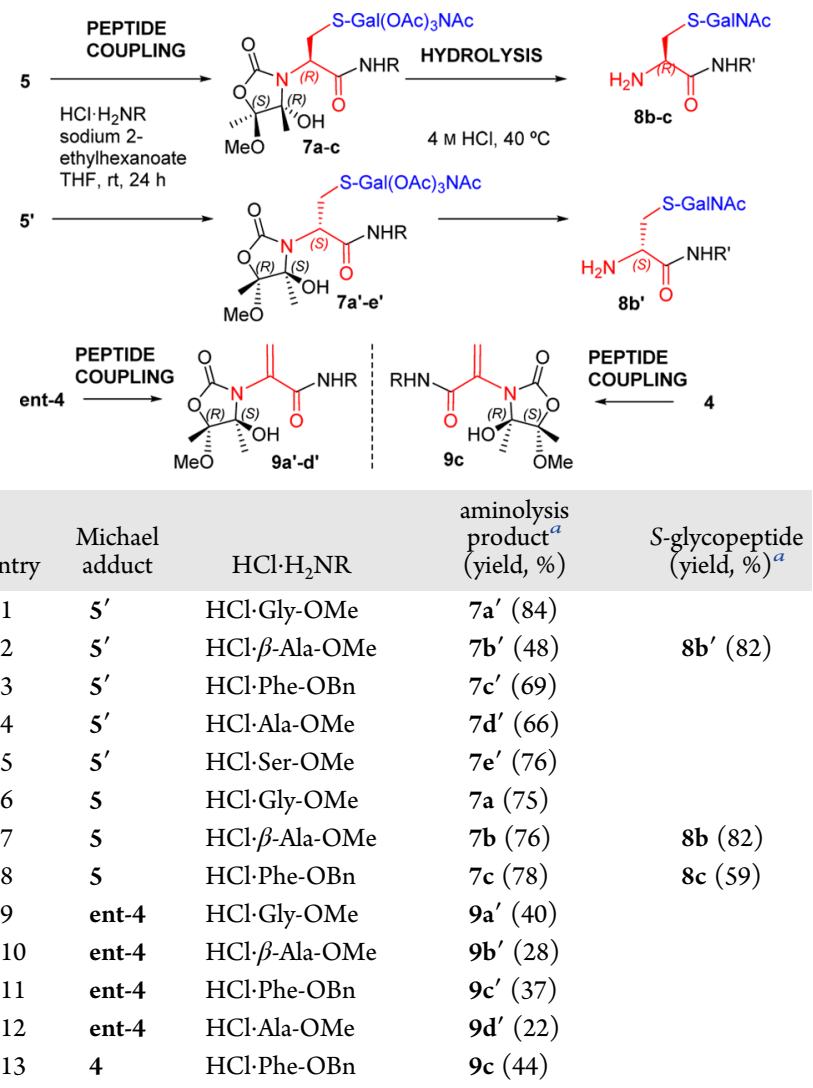

${ }^{a}$ Yields after purification by column chromatograpy.

Scheme 4. S-Michael/Aminolysis vs Aminolysis/S-Michael Reactions on Chiral Dha 4 To Obtain $\alpha$-S-Glycopeptide 8c

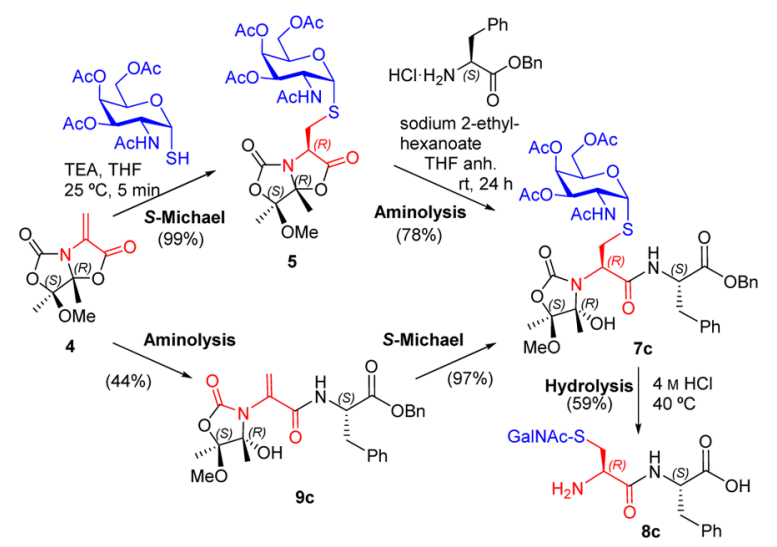

proceeds quickly and at room temperature; therefore it can be regarded as a click reaction. The Michael adduct was easily hydrolyzed to obtain the corresponding glycosyl amino acid $S-\alpha$ D-GalNAc-L-Cys, a mimic of the Tn antigen ( $\alpha$-D-GalNAc-L-Ser). The advantage of this synthetic approach over the previously published work $^{23 b}$ consists of an increase of the yield of the 1,4conjugate addition and the ability to carry out the hydrolysis of the Michael adduct in a clean way, avoiding the problems observed in other cases. ${ }^{23 \mathrm{~b}}$ The oxazolidinone substructure of this new dehydroalanine allows ring-opening reactions with other amino acids to obtain $S$-glycopeptide derivatives in which the sulfa-Tn antigen is incorporated. This methodology is 
currently being expanded in our laboratory to obtain longer glycopeptides of biological relevance.

\section{ASSOCIATED CONTENT}

\section{S Supporting Information}

The Supporting Information is available free of charge on the ACS Publications website at DOI: 10.1021/acs.orglett.6b00840.

Experimental and computational details; copies of NMR spectra (PDF)

$\mathrm{X}$-ray data of 4 (CIF)

$\mathrm{X}$-ray data of $\mathbf{5}$ (CIF)

\section{AUTHOR INFORMATION}

\section{Corresponding Authors}

*E-mail: hector.busto@unirioja.es.

*E-mail: jesusmanuel.peregrina@unirioja.es.

Author Contributions

${ }$ M.I.G.-J. and C.A. contributed equally to this work. Notes

The authors declare no competing financial interest.

\section{ACKNOWLEDGMENTS}

We are grateful to MINECO (Project Nos. CTQ2015-67727-R and UNLR13-4E-1931 to J.M.P., CTQ2015-70524-R and RYC2013-14706 to G.J.-O., and FPI fellowship to C.D.N.). We also thank CESGA and $\mathrm{BiFi}$ (Memento cluster) for computer support.

\section{REFERENCES}

(1) (a) Ju, T.; Otto, V. I.; Cummings, R. Angew. Chem., Int. Ed. 2011, 50, 1770. (b) Westerlind, U.; Schröder, H.; Hobel, A.; Gaidzik, N.; Kaiser, A.; Niemeyer, C. M.; Schmitt, E.; Waldmann, H.; Kunz, H. Angew. Chem., Int. Ed. 2009, 48, 8263. (c) Allen, J. R.; Harris, C. R.; Danishefsky, S. J. J. Am. Chem. Soc. 2001, 123, 1890. (d) Lakshminarayanan, V.; Thompson, P.; Wolfert, M. A.; Buskas, T.; Bradley, J. M.; Pathangey, L. B.; Madsen, C. S.; Cohen, P. A.; Gendler, S. J.; Boons, G.-J. Proc. Natl. Acad. Sci. U. S. A. 2012, 109, 261. (e) Ingale, S.; Wolfert, M. A.; Gaekwad, J.; Buskas, T.; Boons, G. J. Nat. Chem. Biol. 2007, 3, 663. (f) Wilkinson, B. L.; Day, S.; Malins, L. R.; Apostolopoulos, V.; Payne, R. J. Angew. Chem., Int. Ed. 2011, 50, 1635.

(2) (a) Miles, D.; Roche, H.; Martin, M.; Perren, T. J.; Cameron, D. A.; Glaspy, J.; Dodwell, D.; Parker, J.; Mayordomo, J.; Tres, A.; Murray, J. L.; Ibrahim, N. K. Oncologist 2011, 16, 1092. (b) Ohyama, C. Int. J. Clin. Oncol. 2008, 13, 308. (c) Paulsen, H.; Brockhausen, I. Glycoconjugate J. 2001, 18, 867.

(3) (a) Wang, Q.; Guo, Z. ACS Med. Chem. Lett. 2011, 2, 373. (b) Liu, C.-C.; Ye, X.-S. Glycoconjugate J. 2012, 29, 259. (c) Richichi, B.; Thomas, B.; Fiore, M.; Bosco, R.; Qureshi, H.; Nativi, C.; Renaudet, O.; BenMohamed, L. Angew. Chem., Int. Ed. 2014, 53, 11917.

(4) Oberbillig, T.; Mersch, C.; Wagner, S.; Hoffmann-Röder, A. Chem. Commun. 2012, 48, 1487.

(5) (a) Awad, L.; Madani, R.; Gillig, A.; Kolympadi, M.; Philgren, M.; Muhs, A.; Gérard, C.; Vogel, P. Chem. - Eur. J. 2012, 18, 8578. (b) Dondoni, A.; Marra, A. Chem. Rev. 2000, 100, 4395. (c) Peri, F.; Cipolla, L.; Rescigno, M.; La Ferla, B.; Nicotra, F. Bioconjugate Chem. 2001, 12, 325

(6) (a) Rich, J. J.; Bundle, D. R. Org. Lett. 2004, 6, 897. (b) Bousquet, E.; Spadaro, A.; Pappalardo, M. S.; Bernardini, R.; Romeo, R.; Panza, L.; Ronsisvalle, G. J. Carbohydr. Chem. 2000, 19, 527.

(7) Vichier-Guerre, S.; Lo-Man, R.; Huteau, V.; Deriaud, E.; Leclerc, C.; Bay, S. Bioorg. Med. Chem. Lett. 2004, 14, 3567.

(8) Aydillo, C.; Navo, C. D.; Busto, J. H.; Corzana, F.; Zurbano, M. M.; Avenoza, A.; Peregrina, J. M. J. Org. Chem. 2013, 78, 10968.
(9) Geraci, C.; Consoli, G. M.; Galante, E.; Bousquet, E.; Pappalardo, M. S.; Spadaro, A. Bioconjugate Chem. 2008, 19, 751.

(10) Martínez-Sáez, N.; Castro-López, J.; Valero-González, J.; Madariaga, D.; Compañón, I.; Somovilla, V. J.; Salvadó, M.; Asensio, J. L.; Jiménez-Barbero, J.; Avenoza, A.; Busto, J. H.; Bernardes, G. J. L.; Peregrina, J. M.; Hurtado-Guerrero, R.; Corzana, F. Angew. Chem., Int. Ed. 2015, 54, 9830.

(11) (a) Pachamuthu, K.; Schmidt, R. R. Chem. Rev. 2006, 106, 160. (b) Tan, F. Y.Y.; Tang, C. M.; Exley, R. M. Trends Biochem. Sci. 2015, 40, 342. (c) Stepper, J.; Shastri, S.; Loo, T. S.; Preston, J. C.; Novak, P.; Man, P.; Moore, C. H.; Havlíček, V.; Patchett, M. L.; Norris, G. E. FEBS Lett. 2011, 585, 645 .

(12) Venugopal, H.; Edwards, P. J. B.; Schwalbe, M.; Claridge, J. K.; Libich, D. S.; Stepper, J.; Loo, T.; Patchett, M. L.; Norris, G. E.; Pascal, S. M. Biochemistry 2011, 50, 2748.

(13) (a) Oman, T. J.; Boettcher, J. M.; Wang, H.; Okalibe, X. N.; van der Donk, W. A. Nat. Chem. Biol. 2011, 7, 78. (b) Wang, H.; van der Donk, W. A. J. Am. Chem. Soc. 2011, 133, 16394. (c) Wang, H.; Oman, T. J.; Zhang, R.; Garcia de Gonzalo, C. V.; Zhang, Q.; van der Donk, W. A. J. Am. Chem. Soc. 2014, 136, 84.

(14) Taylor, C. M. Tetrahedron 1998, 54, 11317.

(15) (a) Floyd, N.; Vijayakrishnan, B.; Koeppe, J. R.; Davis, B. G. Angew. Chem., Int. Ed. 2009, 48, 7798. (b) Dondoni, A. Angew. Chem., Int. Ed. 2008, 47, 8995. (c) Lázár, L.; Csávás, M.; Herczeg, M.; Herczegh, P.; Borbás, A. Org. Lett. 2012, 14, 4650. (d) Markey, L.; Giordani, S.; Scanlan, E. M. J. Org. Chem. 2013, 78, 4270. (e) Dénès, F.; Pichowicz, M.; Povie, G.; Renaud, P. Chem. Rev. 2014, 114, 2587.

(16) (a) Zhu, X.; Schmidt, R. R. Chem. - Eur. J. 2004, 10, 875. (b) Galonic, D. P.; van der Donk, W. A.; Gin, D. Y. J. Am. Chem. Soc. 2004, 126, 12712. (c) Galonic, D. P.; Ide, N. D.; van der Donk, W. A.; Gin, D. Y. J. Am. Chem. Soc. 2005, 127, 7359.

(17) Thayer, D. A.; Yu, H. N.; Galan, M. C.; Wong, C.-H. Angew. Chem., Int. Ed. 2005, 44, 4596.

(18) Kazmaier, U. Synthesis and Chemistry of $\alpha, \beta$-Didehydroamino Acids. In Amino Acids, Peptides and Proteins in Organic Chemistry; WileyVCH: Weinheim, 2009; Vol. 2, Chapter 1, pp 3-18.

(19) Willey, J. M.; van der Donk, W. A. Annu. Rev. Microbiol. 2007, 61, 477.

(20) (a) Levengood, M. R, van der Donk, W. A. Nat. Protoc. 2007, 1, 3001. (b) Bernardes, G. J. L.; Chalker, J. M.; Errey, J. C.; Davis, B. G. J. Am. Chem. Soc. 2008, 130, 5052. (c) Guo, J.; Wang, J.; Lee, J. S.; Schultz, P. G. Angew. Chem., Int. Ed. 2008, 47, 6399. (d) Haj-Yahya, N.; Hemantha, H. P.; Meledin, R.; Bondalapati, S.; Seenaiah, M.; Brik, A. Org. Lett. 2014, 16, 540. (e) Chalker, J. M.; Lercher, L.; Rose, N. R.; Schofield, C. J.; Davis, B. G. Angew. Chem., Int. Ed. 2012, 51, 1835. (f) Vallée, M. R. J.; Schombs, M. W.; Balaban, Z. J.; Colyer, J.; Davis, B. G. Chem. Commun. 2016, 52, 3014. (g) Grayson, E. J.; Bernardes, G. J. L.; Chalker, J. M.; Boutureira, O.; Koeppe, J. R.; Davis, B. G. Angew. Chem., Int. Ed. 2011, 50, 4127. (h) Chalker, J. M.; Bernardes, G. J. L.; Davis, B. G. Acc. Chem. Res. 2011, 44, 730.

(21) Cohen, S. B.; Halcomb, R. L. J. Am. Chem. Soc. 2002, 124, 2534

(22) (a) Zhu, Y.; van der Donk, W. A. Org. Lett. 2001, 3, 1189. (b) Galonic, D. P.; van der Donk, W. A.; Gin, D. Y. Chem. - Eur. J. 2003, 9, 5997.

(23) (a) Aydillo, C.; Avenoza, A.; Busto, J. H.; Jiménez-Osés, G.; Peregrina, J. M.; Zurbano, M. M. Org. Lett. 2012, 14, 334. (b) Aydillo, C.; Compañón, I.; Avenoza, A.; Busto, J. H.; Corzana, F.; Peregrina, J. M.; Zurbano, M. M. J. Am. Chem. Soc. 2014, 136, 789.

(24) Knapp, S.; Myers, D. S. J. Org. Chem. 2002, 67, 2995.

(25) Wang, H.; Houk, K. N. Chem. Sci. 2014, 5, 462.

(26) Boutureira, O.; Bernardes, G. J. L. Chem. Rev. 2015, 115, 2174. 